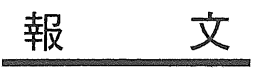

\title{
電気伝導度検出器を用いた高速液体クロマトグラフィー によるアニオン界面活性剤の分析
}

\author{
近藤 征 弘 \\ 花王株式会社・研究所 \\ （广321-34 栃木県芳賀郡市貝町赤羽 2606）
}

\begin{abstract}
Analysis of Anionic Surfactants by High-Performance Liquid Chromatography with Conductive Detector
\end{abstract}

Yukihiro KONDOH

Kao Research Laboratories, Kao Corporation, 2606, (Akabane Ichikai-machi, Haga-gun, Tochigi-ken, $\bar{\top} 321-34$ )

\begin{abstract}
A high-performance liquid chromatographic method with high sensitivity and selectivity for analysis of anionic surfactants (ASF) is described. ASF such as alkylbenzenesulfonate (LAS), alkanesulfonate (SAS), $\alpha$-olefinsulfonate (AOS), alkyl sulfate (AS) and poly (oxyethylene) alkyl ether sulfate (ES) were separated by reversed-phase chromatography using ODS-silica (Hitachi gel 3053$)$ as a stationary phase and $1 \mathrm{mM}$ sodium perchlorate in acetonitrile-water $(30: 70)$ as a mobile phase and were detected with non-suppressor type conductive detector. The calibration curve was linear in the range from 0.005 to $17 \mu \mathrm{g}$ for $\mathrm{C}_{12} \mathrm{AS}-\mathrm{Na}$ and the relative standard deviation with five measurements was $0.31 \%$ for $1.0 \mu \mathrm{g} \mathrm{C}_{12} \mathrm{AS}-\mathrm{Na}$. The results of homolog analysis of LAS by the proposed method showed good agreement with those by the UV detection. Nonionic, cationic and amphoteric surfactants did not interfere with the analysis of ASF. By the proposed method, ASF in commercial household and cosmetic products were analyzed with high sensitivity and selectivity. Better separations were achieved by the gradient elution method.
\end{abstract}

\section{1 緒言}

洗剤, シャンプーなどの家庭用製品及び化粧品に利用 されている界面活性剂の多くはアニオン界面活性剂 (ASF) である。ASF の中には直鎖アルキルベンゼンス ルホン酸塩 (LAS), アルカンスルホン酸塩 (SAS), 硫 酸アルキル塩 $(\mathrm{AS})$ 及び硫酸アルキルポリ（オキシエチ レン) 塩 (ES) など, 数多くの種類があるが, 市販の ASF はいずれもアルキル基に分布を有する混合物から なる。一般に, 製品中の $\mathrm{ASF}$ を簡便, 迅速に同定する には薄層クロマトグラフィー $(\mathrm{TLC})^{1) \sim 3)}$ が用いられて いるが，この方法ではアルキル組成に関する情報は得 られない。ASF の組成分析に関してはガスクロマト グラフィー $(\mathrm{GC})^{4) \sim 8)}$ や高速液体クロマトグラフィー $(\mathrm{HPLC})^{9) \sim 15)}$ が主として用いられる。GCは, 製品中 に含まれる混合界面活性剂からあらかじめ ASF を単離 した後, 揮発性成分に誘導体化するなどの煩雑な前処理
操作を必要とする。一方, HPLC は難揮発性成分を前 処理することなく分析することが可能であるため，盛ん に研究されているが, 改良すべき点も多い。例えば,

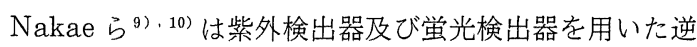
相クロマトグラフィーにより, LAS の親油基分析及び 微量定量を行っているが, SAS, AS 及び ES などの ASF の多くは，いず机も UV 吸収や蛍光を有しないた め, 検出法が問題となっている。また, Nakamura $ら^{11)}$, 12) は, 示差屈折率 (RI) 検出器を用いた逆相ク口 マトグラフィーにより，種々のイオン性及び非イオン性 界面活性剂混合物の分離分析を行っているが, RI 検出 器は選択性に欠けるため, 製品の分析に際しては複雑な クロマトグラムとなり，かつ，感度も低い。したがって， 製品中に配合された ASF を精度良く分析するためには 選択的検出法が不可欠であり，種々の試みが行われてい る。最近, Nakae ら ${ }^{13)}$ はニュートラルレッドをイオン 対試薬として用いるイオン対抽出検出器 (IPED) を開 
発し, Smedes ら ${ }^{14)}$ 及び Kanesato ら ${ }^{15)}$ もアリジニ ウムクロリドとメチレンブルーをイオン対試薬として 用いる IPED による分析法を報告している。しかし, IPED もアルキル鎖の違いにより感度が異なるなど定量 性に問題があり, また，ポストカラム法であるためピー クの広がりによる分離能の低下は避けられない。一方, Weiss ${ }^{16)}$ はジビニルベンゼン樹脂を固定相に, 水酸化 アンモニウムまたはテトラアルキルアンモニウムニヒド ロキシドを含むアセトニトリルー水を移動相に用い, サ プレッサー型電気伝導度検出器を用いるイオンクロマト グラフィーにより, SAS, AS 及び $\alpha$ ーオレフィンスル ホン酸塩 (AOS) の分析を行った。また, Kunitani ら ${ }^{17)}$ も同法によるAS の定量性について検討しているが, 洗 剤やシャンプーなどの実使用の家庭用製品及び化粧品の 分析に応用してはいない。

本報では, 最も一般的に用いられている逆相充填剂で ある ODS シリカを固定相に用い, 検出器としてノンサ プレッサー型電気伝導度検出器を用いることにより, 製 品中の ASF の簡便で選択的, 高感度な分析法を検討し た。

\section{2 実験}

\section{$2 \cdot 1$ 装 置}

高速液体クロマトグラフは送液ポンプ（日立製，655 -11 型)，グラジェントコントローラー（日立製，L5000 型)，サンプルインジェクター(Reodyne 製, 7125 型), カラム恒温槽 (島津製, CTO-6 A 型), 電気伝導 度検出器 (東ソー製, $\mathrm{CM}-8$ 型) 及びデー夕処理装置 （㯺津製，クロマトパック C-R 3 A 型）よりなる。

\section{$2 \cdot 2$ 試薬及び試料}

固定相には主として $5 \mu \mathrm{m}$ の球状 ODS シリカである 日立ゲル 3053 を用い, 比較のために LiChrospher RP -18, LiChrospher RP-18 (e), Zorbax ODS 及び Wakosil $5 \mathrm{C}_{18}$ を用いた。アセトニトリルは高速液体ク ロマトグラフ分析用溶媒 (関東化学) を用いた。直鎖ド デシルベンゼンスルホン酸ナトリウム (DBS) は和光純 薬製 (ABS 測定用) を, テトラデカンスルホン酸ナト リウムは東京化成工業製を用いた。 $\mathrm{C}_{12}, \mathrm{C}_{14}, \mathrm{C}_{16}$ の硫

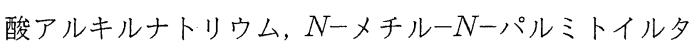

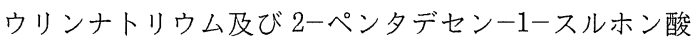
ナトリウムはいずれも実験室合成品を再結晶して用い た。その他の試薬はいずれも試薬特級品を用いた。

\section{$2 \cdot 3$ 分析操作}

分析カラムには日立ゲル 3053 を充䭫した内径 4.0 $\mathrm{mm}$, 長さ $150 \mathrm{~mm}$ のステンレス管を用い, カラム温 度は $40^{\circ} \mathrm{C}$ に保った。定組成溶離法では溶離液として 1.0 $\mathrm{mM}$ 過塩素酸ナトリウムを含むアセトニトリルー水 (30：70) を用い, $1.5 \mathrm{~mL} / \mathrm{min}$ の流速で送液した。一
Table-1 Time program of the gradient elution.

\begin{tabular}{c|c|c}
\hline Time (min) & Solvent A (\%) & Solvent B (\%) \\
\hline 0 & 100 & 0 \\
8 & 50 & 50 \\
25 & 0 & 100 \\
30 & 0 & 100 \\
30.1 & 100 & 0 \\
45 & 100 & 0 \\
\hline
\end{tabular}

方, グラジェント溶離法では溶離液として $1.0 \mathrm{mM}$ 過 塩素酸ナトリウムを含むアセトニトリルー水 $(10: 90)$ ( $\mathrm{A}$ 液), $1.1 \mathrm{mM}$ 過塩素酸ナトリウムを含むアセトニト リルー水 $(40: 60)$ (B 液)を用い, 流速 $1.5 \mathrm{~mL} / \mathrm{min}$ で, Table-1 に示したタイムプログラムにより分析し た。なお，グラジェント溶離法ではベースラインのドリ フトが大きいため, ベースライン補正を行った。溶離液 に溶解した試料 $5 \sim 50 \mu \mathrm{L}$ を注入し，そのピーク面積を 測定した。

試料中にアンモニアやトリエタノールアミンなどのア ルカノールアミンが含まれている場合には, 試料をメ夕 ノールに溶かした後 (ASF が 10〜5000 ppm となるよ うに), その $5 \mathrm{~mL}$ を採取し TOYOPAK IC-SP M (東ソー製)を通過させた。さらに, メタノール約 $10 \mathrm{~mL}$ で洗浄し, 洗液を合わせた後, $0.2 \% p$ 一ニトロフェノー ルを 2 滴加え, $0.1 \mathrm{~N}$ 水酸化ナトリウムで中和した。さ らに, 溶媒を留去した後, 溶離液を加えて $25 \mathrm{~mL} と し$, 測定に供した。

\section{3 結果と考察}

\section{$3 \cdot 1$ 分離条件の検討}

Nakae らは, 紫外検出器を用いた HPLC による ASF (LAS) の分析をするため, 固定相として日立ゲル 3053 を, 溶離液に $0.1 \mathrm{M}$ 過塩素酸ナトリウムを含むアセ卜 ニトリルー水 $(45: 55)$ を用いており ${ }^{9)}$ ，また，Nakamura らによるイオン性及び非イオン性界面活性剤の分 析においても, 溶離液として $0.4 \mathrm{M}$ 塩化ナトリウムま たは $1 \mathrm{M}$ 過塩素酸ナトリウムを含むメタノールー水

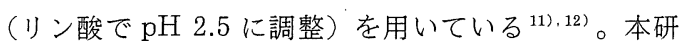
究では, 検出器としてノンサプレッサー型電気伝導度検 出器を用いるため, 溶離液中の塩の濃度を減少させ, バッ クグラウンドの電気伝導度を下げる必要があると考えら れる。そこでまず，ASFとしてDBSを用い，その分離 に及ぼす過塩素酸ナトリウム濃度の影響を, UV 検出器 を用いた HPLCにより検討を試みることにした。カラ ムとして日立ゲル 3053 を用い, アセトニトリル含量を 45 \%に固定し，DBSのk浓す過塩素酸ナトリウム濃 度の影響を調べることにした。その結果を Fig.-1 に示 


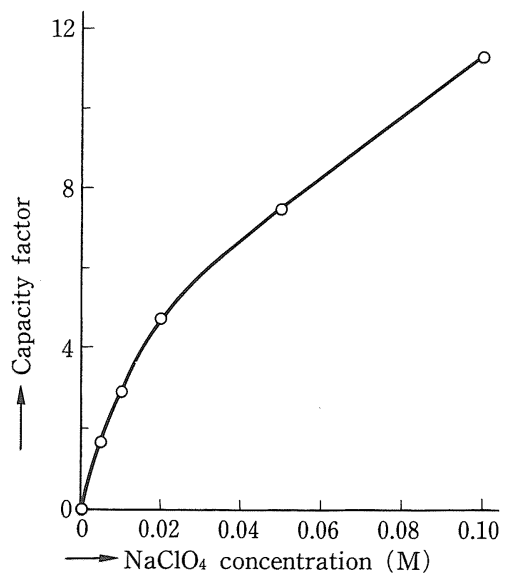

Conditions : column : Hitachi gel 3053, 4.0 $\mathrm{mm}$ i.d. $\times 150 \mathrm{~mm}$; eluent : $0.005 \sim 0.10 \mathrm{M}$ $\mathrm{NaClO}_{4}$ in acetonitrile-water (45:55); flow rate: $1.5 \mathrm{~mL} / \mathrm{min}$; column temperature : $40{ }^{\circ} \mathrm{C}$; detector : UV $225 \mathrm{~nm}$. Capacity factors of 2-phenyl isomer of DBS were plotted.

Fig.-1 Effect of the concentration of sodium perchlorate on the capacity factor of DBS.

す。 $k^{\prime}$ は過塩素酸ナトリウム濃度の増加に伴い増大し, この傾向は Smedesら ${ }^{14)}$ の結果と一致した。次に図に は示していないが, 過塩素酸ナトリウム濃度を $1 \mathrm{mM}$ に固定し，アセトニトリル含量を変化させたところ，ア セトニトリル含量の隇少に伴い強く保持され，アセトニ トリル含量が 30\%において Nakae ら ${ }^{9)}$ の結果とほぼ同 程度の分離が得られた。この分離条件において, 検出器 として電気伝導度検出器を用いて LAS-Na, AS-Na 標準混合物及びC $\mathrm{C}_{12}$ の $\mathrm{ES}-\mathrm{Na}$ を分析した際のクロマト グラムはいず机も良好な分離が得ら机た (Fig.-2)。図 には示していないが, 塩の種類について検討を行ったと ころ, フッ化ナトリウム, 塩化ナトリウム, 臭化ナトリ ウム, ヨウ化ナトリウム, 硝酸ナトリウム, リン酸二水 素ナトリウムなどの無機塩, ギ酸ナトリウム, 酷酸ナト リウム，安息香酸ナトリウム，サリチル酸ナトリウム， フタル酸ナトリウムなどの有機酸塩を用いても過塩素酸 ナトリウムとほぼ同程度の分離が得られた。また, ナト リウム以外のリチウム, カリウム, アンモ二ウム塩を用 いた場合にも同程度の分離が得られたが，クロマトグラ ム上に不明な負ピークが現れた。この負ピークは ODS シリカ中のシラノール基がイオン交換基として作用し, ASF の対イオンであるナトリウムイオンが溶出するこ 之によるものであると推定された。さらに，固定相につ いて, 市販の ODS シリカ系の充壝剂数種を用いて検討 したところ，保持挙動はいずれも基本的に同じであった

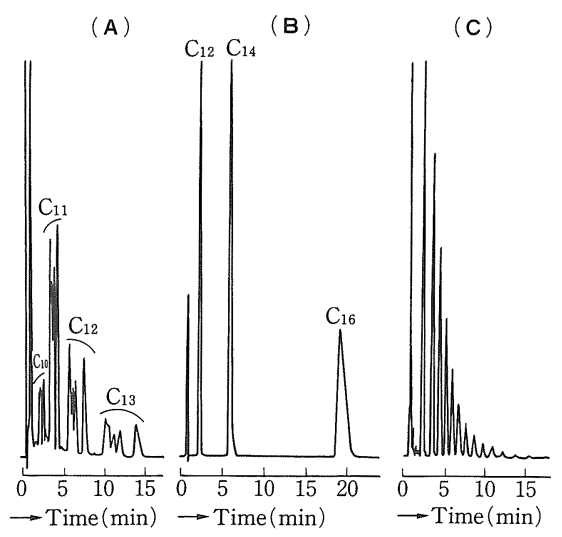

(A) LAS-Na, (B) AS-Na, (C) $\mathrm{C}_{12} \mathrm{ES}-$ $\mathrm{Na}$ Conditions : eluent : $1.0 \mathrm{mM} \mathrm{NaClO}_{4}$ in acetonitrile-water $(30: 70)$; detector : conductive detector. Other conditions are the same as in Fig. -1 .

Fig. -2 Chromatograms of anionic surfactants with isocratic elution.

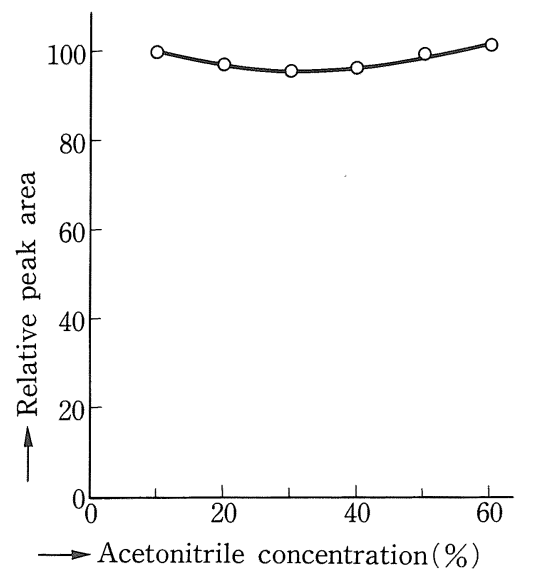

Conditions : eluent : $1.0 \mathrm{mM} \mathrm{NaClO}_{4}$ in acetonitrile-water. Other conditions are the same as in Fig. -2. Sample: DBS 10 $\mu \mathrm{g}$.

Fig. -3 Effect of the concentration of acetonitrile in mobile phase on the sensitivity.

が, $1 \mathrm{mM}$ 程度の塩濃度では良好なピーク形が得られな いものが多く, 日立ゲル 3053 が最も良好であった。

\section{$3 \cdot 2$ 溶離液組成の検出感度に及ぼす影響}

DBS を用いて溶離液組成の検出感度に及ぼす影響を 検討した。Fig.ー3 は溶離液中の水含量のピーク面積に 及ぼす影響を示す。Fig.ー3 から明らかなように，アセ トニトリル含量が 10〜 $60 \%$ の範囲では相対検出感度は 96〜101\%であり，大きな変化は認められなかった。 


\section{$3 \cdot 3 \quad$ 相対モル感度}

AS を用いてアルキル鎖長の違いによる感度の比較を 行った (Table-2)。アルキル鎖長に依存せずほぼ等し いモル感度で検出できることが確認された。また, LAS のアルキル組成分析の本法による值と紫外検出法 ${ }^{9)}$ に よる值を比較したところ，両者は良好な一致を示し た(Table-3)。さらに, 本法による種々の ASF の相対 モル感度を求めたところ, ASF の種類に依存せずほぼ 同じ感度で検出可能であることが分かった (Table-4)。

\section{$3 \cdot 4$ 検量線及び再現性}

$\mathrm{AS}-\mathrm{Na}\left(\mathrm{C}_{12}, \mathrm{C}_{14}, \mathrm{C}_{16}\right)$ 及び DBS についておのおの 検量線を作成したところ, いずれも広い範囲で良好な直 線性を有する検量線が得られ, $1.0 \mu \mathrm{g}$ または $3.0 \mu \mathrm{g}$ 注 入における再現性も良好であった $($ Table-5)。

\section{$3 \cdot 5$ 選 択 性}

本法ではイオン性界面活性剂を選択的に検出できるた め, 非イオン界面活性剤は検出されない。また, ODS シリカを用いたカチオン界面活性剂の分析では溶離液中

Table-2 Relative molar response of the homologs of AS.

\begin{tabular}{c|c|c}
\hline \multirow{2}{*}{$\begin{array}{c}\text { Alkyl chain } \\
\text { length }\end{array}$} & \multicolumn{2}{|c}{ Relative molar response } \\
\cline { 2 - 3 } & Isocratic elution & Gradient elution \\
\hline $\mathrm{C}_{12}$ & 1.00 & 1.00 \\
$\mathrm{C}_{14}$ & 0.98 & 0.99 \\
$\mathrm{C}_{16}$ & 0.98 & 0.98 \\
\hline
\end{tabular}

a) Relative molar response to $\mathrm{C}_{12} \mathrm{AS}$.
に過塩素酸ナトリウム等の塩を $0.1 \mathrm{M}$ 程度添加する必

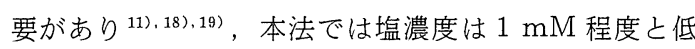
く，アセトニトリル含量も少ないため，アルキルトリメ

Table-3 Comparison of the result of homolog analysis of LAS by the proposed method with that by the UV detection $\operatorname{method}^{7)}$.

\begin{tabular}{|c|c|c|}
\hline $\begin{array}{l}\text { Alkyl chain length and } \\
\text { isomer distribution }\end{array}$ & $\begin{array}{l}\text { Proposed } \\
\text { method }^{\text {a) }}\end{array}$ & $\begin{array}{l}\text { UV detection } \\
\text { method }^{\text {a) }}\end{array}$ \\
\hline $\mathrm{C}_{10}$ & 8.1 & 8.4 \\
\hline 4-to 5-phenyl & 2.2 & 2.3 \\
\hline 3-phenyl & 2.3 & 2.2 \\
\hline 2-phenyl & 3.6 & 3.9 \\
\hline $\mathrm{C}_{11}$ & 40.4 & 40.2 \\
\hline 4 -to 6-phenyl & 17.0 & 17.5 \\
\hline 3-phenyl & 9.6 & 9.3 \\
\hline 2-phenyl & 13.8 & 13.4 \\
\hline $\mathrm{C}_{12}$ & 30.4 & 30.7 \\
\hline 5-to 6-phenyl & 9.0 & 9.5 \\
\hline 4-phenyl & 4.9 & 5.1 \\
\hline 3-phenyl & 6.2 & 6.3 \\
\hline 2-phenyl & 10.3 & 9.8 \\
\hline $\mathrm{C}_{13}$ & 21.1 & 20.7 \\
\hline 5-to 7-phenyl & 7.4 & 7.3 \\
\hline 4-phenyl & 3.1 & 3.3 \\
\hline 3-phenyl & 4.1 & 4.0 \\
\hline 2-phenyl & 6.5 & 6.1 \\
\hline
\end{tabular}

a) Presented as peak area $\%$.

Table-4 Relative molar response of several anionic surfactants.

\begin{tabular}{l|c}
\multicolumn{1}{c|}{ Anionic surfactant } & Relative molar response $^{\text {a) }}$ \\
\hline Sodium dodecylbenzenesulfonate & 0.98 \\
Sodium tetradecanesulfonate & 0.97 \\
Sodium 2-pentadecene-1-sulfonate & 1.02 \\
Sodium $N$-methyl- $N$-palmitoyltaurate & 0.98 \\
Sodium dodecyl sulfate & 1.00 \\
\hline
\end{tabular}

a) Relative molar response to sodium dodecyl sulfate.

Table-5 Range of calibration curves and reproducibilities of AS and DBS.

\begin{tabular}{l|c|c|c|c}
\hline \multicolumn{1}{c|}{ Surfactant } & $\begin{array}{c}\text { Range of } \\
\text { calibration } \\
\text { curve }(\mu \mathrm{g})\end{array}$ & $\begin{array}{c}\text { Coefficient of } \\
\text { correlation }\end{array}$ & $\begin{array}{c}\text { R. S. D. }{ }^{\text {a }} \\
(\%)\end{array}$ & $\begin{array}{c}\text { Injection } \\
\text { amount } \\
(\mu \mathrm{g})\end{array}$ \\
\hline Sodium dodecyl sulfate & $0.005 \sim 17$ & 0.9999 & 0.31 & 1.0 \\
Sodium tetradecyl sulfate & $0.020 \sim 19$ & 0.9999 & 0.60 & 1.0 \\
Sodium hexadecyl sulfate & $0.050 \sim 21$ & 0.9999 & 1.12 & 1.0 \\
Sodium dodecylbenzenesulfonate & $0.050 \sim 30$ & 0.9998 & 1.35 & 3.0 \\
\hline
\end{tabular}

a) Relative standard deviation $(n=5)$. 
チルアンモニウム塩, ジアルキルジメチルアンモニウム 塩などのカチオン界面活性剤は本条件ではいずれもカラ ムに強く保持され, 溶出しない。また, ベタイン型及び イミダゾリン型両性界面活性剤も本条件では検出されな かった。このように, 本法では ASF のみを選択的に検 出することが可能である。

\section{6 実試料の分析}

本法により市販のシャンプーを何ら前処理することな く分析した際のクロマトグラムの一例を Fig.-4 に示 す。

Fig.-4 から明らかなように, 溶離液に溶かして注入 するのみで ASF を選択的, 高感度に分析できた。しか し, 試料中にアンモニアやトリエタノールアミン，モノ エタノールアミンなどのアルカノールアミンが含まれて いる場合には, $3 \cdot 1$ 項に示したように, シラノール基が イオン交換基として作用するため, クロマトグラム上に これらに由来する負ピークまたは正ピークが出現し，妨 害となる場合があった。Fig.-5 (A) にその一例として $\mathrm{AS}$ 及び ES のアンモニウム塩を含む市販のシャンプー を分析した際のクロマトグラムを示す。このような場合 には, $2 \cdot 3$ 項に示した前処理用イオン交換カラムを用い る操作によって，その妨害を除くことができた [Fig.$5(\mathrm{~B})$ ]。 $\mathrm{C}_{14}$ の AS を用いて本操作における回収率を求 めたところ, 回収率は $100.6 \%$ であった。なお，家庭用 製品では硫酸エステル型 ASF とスルホン酸型 ASF が 混合して用いられる場合があるが, 硫酸エステル型 ASF を酸分解した後, 本法により分析することによりスルホ ン酸型 ASF のみを分析することが可能であると考えら 扎 ${ }^{13)}$. 20)。

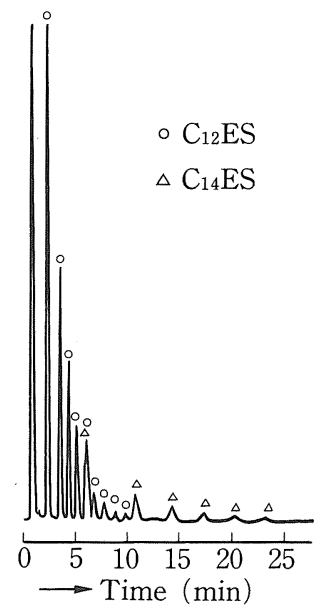

Chromatographic conditions are the same as in Fig. -2 .

Fig. -4 Analysis of anionic surfactants in a commercial shampoo.
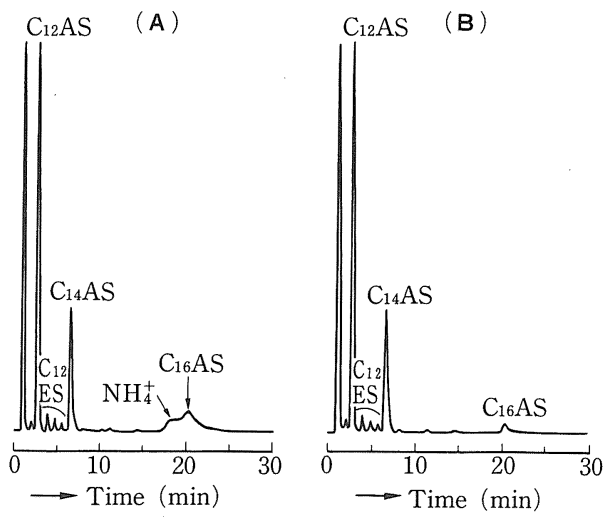

Chromatographic conditions are the same as in Fig. -2 .

Fig. -5 Analysis of anionic surfactants in a commercial shampoo without pretreatment (A) and with pretreatment (B).

\section{$3 \cdot 7$ グラジェント溶離法による分析}

Fig.-6に, 種々の溶離液組成における ASF(LAS) の $k^{\prime}$ とアルキル鎖長の関係を示す。溶離液として 1.0 $\mathrm{mM}$ 過塩素酸ナトリウムを含むアセトニトリルー水 (30：70), $0.1 \mathrm{M}$ 過塩素酸ナトリウムを含むアセトニト リルー水 $(45: 55)$ 及び $0.1 \mathrm{M}$ 過塩素酸ナトリウムを含 むアセトニトリルー水 $(50: 50)$ の 3 種を用いた際の比 較を示したが, $1.0 \mathrm{mM}$ 過塩素酸ナトリウムを含むアセ

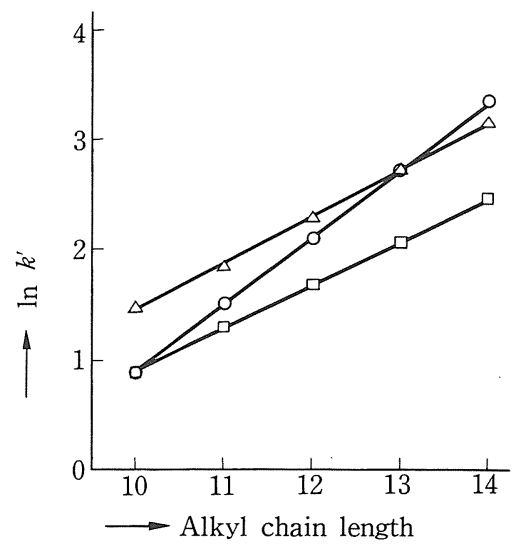

Conditions : eluent : $-\mathrm{O}-1.0 \mathrm{mM} \mathrm{NaClO}_{4}$ in acetonitrile-water $(30: 70) ;-\triangle-0.1$ $\mathrm{M} \mathrm{NaClO}_{4}$ in acetonitrile-water (45: $55)$; $-\square-0.1 \mathrm{M} \mathrm{NaClO}_{4}$ in acetonitrilewater $(50: 50)$. Other conditions are the same as in Fig.-1. Capacity factors of 2phenyl isomer of LAS were plotted.

Fig. -6 Relationships between the capacity factor of LAS and their alkyl chain length. 
トニトリルー水(30：70) を用いた場合は $0.1 \mathrm{M}$ 過塩素 酸ナトリウムを含むアセトニトリルー水 $(45: 55)$ 及び (50：50）を用いた場合に比べ，長いアルキル鎖長を有 するASF の溶出が遅くなると共に，ピーク形が悪化す る傾向が認められた。一方, 短鎖の ASF では製品中に 含まれる無機塩との分離が不充分となる場合もあった。 そこで，短鎖から長鎖までの ASF を同時に分析するた め,グラジェント溶離法による分析を検討した。過塩素 酸ナトリウム濃度及びアセトニトリル含量の最適化を検 討したところ, 溶出力とベースラインの変動を考慮して

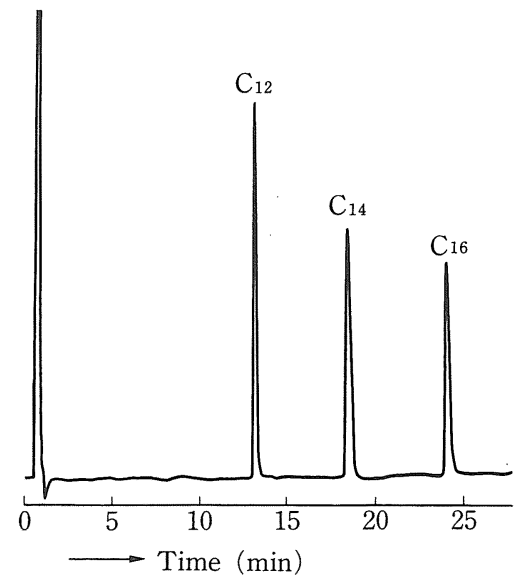

Conditions : eluent : $1.0 \mathrm{mM} \mathrm{NaClO}_{4}$ in acetonitrile-water (10:90) (solvent $\mathrm{A}$ ); $1.1 \mathrm{mM} \mathrm{NaClO}_{4}$ in acetonitrile-water (40 : 60) (solvent B) ; gradient time program is shown in Table-1. Other conditions are the same as in Fig. -2 .

Fig.-7 Chromatogram of $\mathrm{AS}-\mathrm{Na}$ with gradient elution.
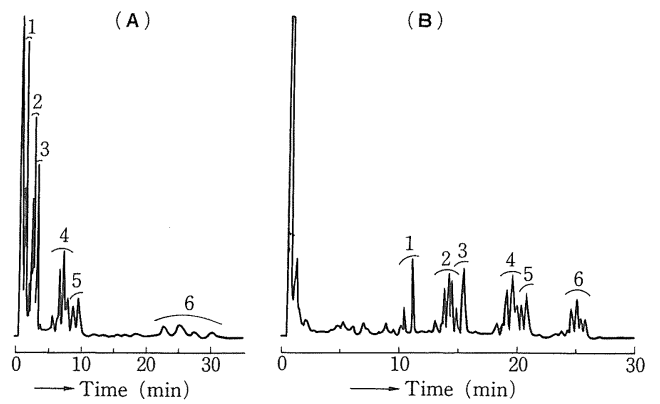

Chromatographic conditions are the same as in Fig. -2 and Fig. -7. 1, $\mathrm{C}_{14}$ hydroxy ; $2, \mathrm{C}_{14}$ alkenyl ; $3, \mathrm{C}_{16}$ hydroxy ; $4, \mathrm{C}_{16}$ alkenyl ; $5, \mathrm{C}_{18}$ hydroxy ; $6, \mathrm{C}_{18}$ alkenyl.

Fig. -8 Chromatogram of AOS-Na with isocratic elution (A) and gradient elution (B).
$2 \cdot 3$ 項に示した溶離液及びグラジェントタイムプログラ ムを決定した。本グラジェント溶離法を用いれば, ベー スラインのドリフトはあるものの, ベースライン補正を 行うこよによりほぼ満足のいくベースラインが得られ た。しかし, 定組成溶離法に比べると 10 倍程度の感度 （S/N 比）の低下は避けられなかった。グラジェント溶 離法により $\mathrm{AS}-\mathrm{Na}$ 標準混合物を分析した際のクロマ トグラムを Fig.-7 に示す。Fig.-2 と比べるとより良 好なピークが得られた。また, Table-2に示すように 相対モル感度も， $\mathrm{C}_{12}, \mathrm{C}_{14}, \mathrm{C}_{16}$ の $\mathrm{AS}$ では大きな変化は 認められなかった。これはFig.ー3の結果からも予想さ れるように, 10\%から 40\%程度のアセトニトリル含量 の変化では検出感度はあまり变化しないためであると考 えられる。Fig.-8 に $\mathrm{C}_{14}, \mathrm{C}_{16}$ 及び $\mathrm{C}_{18}$ の AOS-Na 混 合物を定組成溶離法とグラジェント溶離法の両者で分析 した際のクロマトグラムを示す。グラジェント溶離法で は $\mathrm{C}_{14}$ のヒドロキシ体から $\mathrm{C}_{18}$ のアルケニル体まで良好 に分離することが可能であった。

\section{4 総括}

電気伝導度検出器を用いた HPLC によるASF の分 析法を検討した。ASF を日立ゲル 3053 を固定相に, $1.0 \mathrm{mM}$ 過塩素酸ナトリウムを含むアセトニトリルー水 (30：70) を移動相に用いる逆相クロマトグラフィーで 分離した後, ノンサプレサー型電気伝導検出器により高 感度で選択的に分析することができた。検量線は $\mathrm{C}_{12}$ の AS-Na の場合, 0.005 17 $\mu \mathrm{g}$ の範囲で良好な直線性を 示し, 再現性も良好であった。本法によるLAS のアル キル組成分析の值は紫外検出器による值と良好な一致を 示した。また, 非イオン, カチオン及び両性界面活性剂 は妨害しなかった。本法を市販の家庭用製品及び化粧品 中の ASF の分析に応用することができた。さらに，グ ラジェント溶離法によってより高分離な分析ができた。

本研究を進めるに当たり, 実験に協力して頂いた飯田 国夫君に感謝致します。

[平成 3 年 (1991 年) 1 月 24 日受理]

\section{文献}

1) 高木 徹, 福住一雄, 油化学, 13, 520 (1964)

2) M. Mutter, Tenside Deterg., 5, 138 (1969)

3) 米勢千鶴男, 宍戸 健, 金子隆英, 丸山一茂, 油化学, 27, 592 (1978)

4) J.D. Knight, R. House, J. Am. Oil Chem. Soc., 36, 195 (1959)

5) H.L. Lew, J. Am. Oil Chem. Soc., 44, 359 (1967)

6) H.L. Lew, J. Am. Oil Chem. Soc., 49, 665 (1972)

7) 西 末雄, 分析化学, 14, 917 (1965)

8) 松谷成晃, 繁 猛, 永井俊雄, 油化学, 28, 847 (1979)

9) A. Nakae, K. Tsuji, M. Yamanaka, Anal. 
Chem., 53, 1818 (1981)

10) A. Nakae, K. Tsuji, Chem., 52, 2275 (1980)

11) K. Nakamura, Y. Morikawa, I. Matsumoto, J. Am. Oil Chem. Soc., 58, 72 (1981)

12) K. Nakamura, Y. Morikawa, J. Am. Oil Chem. Soc., 61, 1130 (1984)

13) A. Nakae, K. Tsuji, Comun. Jorn. Com. Esp. Deterg., 14, 133 (1983)

14) F. Smedes, J.C. Kraak, C.F. Werkhoven-Goewie, U.A. Th. Brinkman, R.W. Frei, J. Chro- matogr., 247, 123 (1982)

15) M. Kanesato, K. Nakamura, O. Nakata, Y. Morikawa, J. Am. Oil Chem. Soc., 64, 434 (1987)

16) J. Weiss, J. Chromatogr., 353, 303(1986)

17) M.G. Kunitani, L.M. Kresin, Anal. Biochem., 182, 103 (1989)

18) J. Kawase, J. Chromatogr., 262, 293 (1983)

19) S.L. Abidi, J. Chromatogr., 324, 209 (1985)

20）界面活性剂分析研究会編, “界面活性剂分析法” , 幸書 房(1975), p. 153

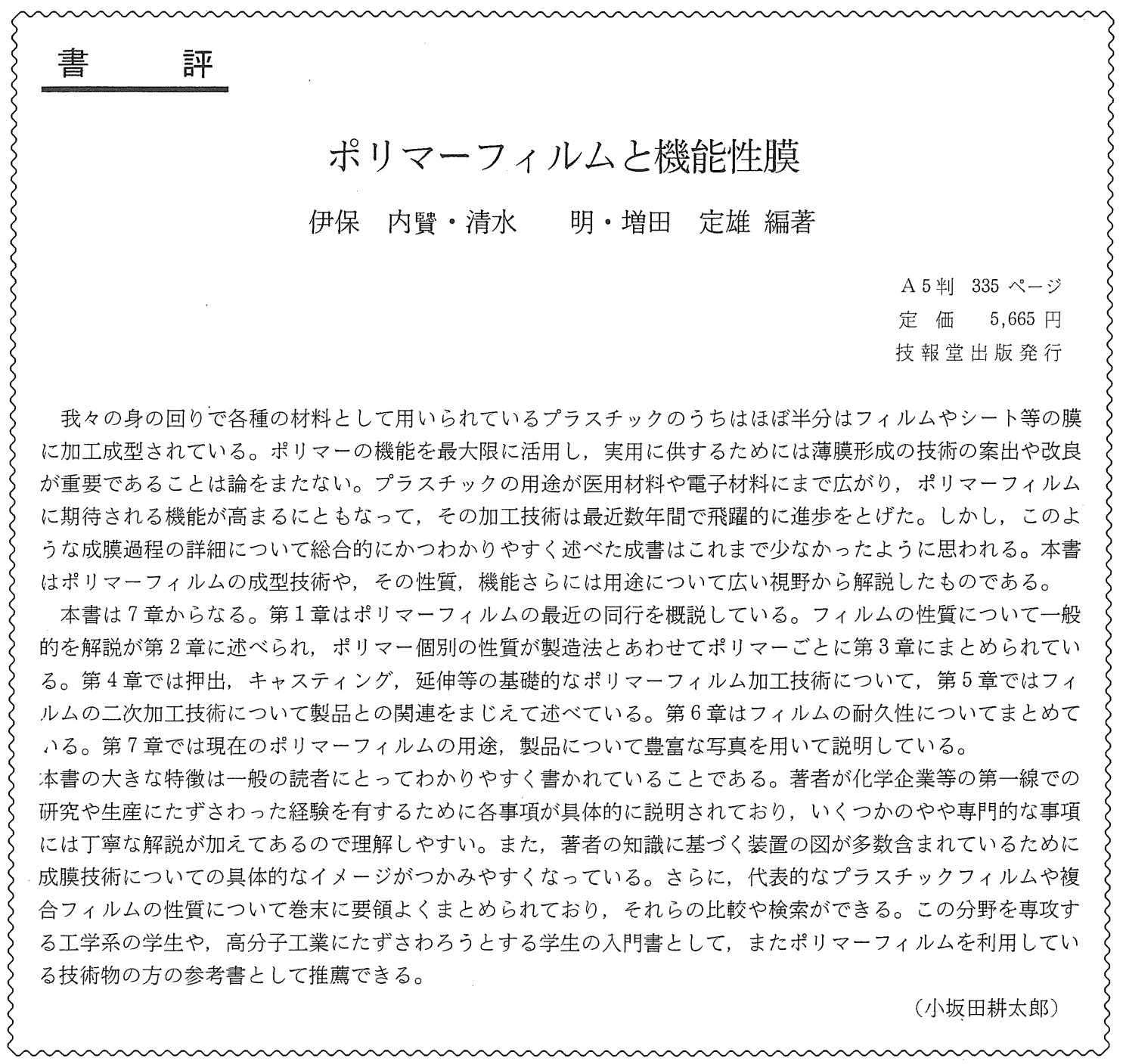

